\title{
Medicinal Plants in Pregnancy and Lactation: Perception of the Health Risk and Practical Educational Group in Araraquara, São Paulo State, Brazil
}

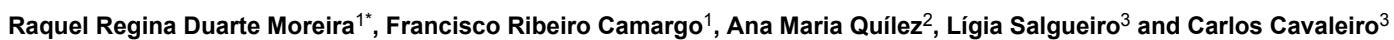

${ }^{1}$ Departamento de Princípios Ativos Naturais Toxicologia, Faculdade de Ciências Farmacêuticas, UNESP- Universidade Estadual Paulista "Júlio de Mesquita Filho", Rodovia Araraquara- Jau km 1, s/n, CEP: 14801-902, Araraquara, São Paulo state, Brazil

${ }^{2}$ Universidad de Sevilla/Colegio Oficiale de Farmacéuticos de Sevilla, Spain

${ }^{3}$ Centro de Estudos Farmacêuticos, Faculdade de Farmácia, Universidade de Coimbra, Portugal

"Corresponding author: Raquel Regina Duarte Moreira, Departamento de Princípios Ativos Naturais Toxicologia, Faculdade de Ciências Farmacêuticas, UNESPUniversidade Estadual Paulista “Júlio de Mesquita Filho", Rodovia Araraquara- Jau km 1, s/n, CEP: 14801-902, Araraquara, São Paulo state, Brazil, Tel: 551633016992; E-mail: raquelrioclaro@gmail.com

Received date: October 2, 2014; Accepted date: December 29, 2014; Published date: December 31, 2014

Copyright: (c) 2014 Moreira RRD, et al. This is an open-access article distributed under the terms of the Creative Commons Attribution License, which permits unrestricted use, distribution, and reproduction in any medium, provided the original author and source are credited.

\begin{abstract}
The use of medicinal plants among pregnant women and lactating is a common practice in diverse countries. However, many medicinal plants are contraindicated during pregnancy and lactating, due to various adverse effects, such as teratogenic, embryotoxic and abortive effects, exposing these women, their fetus and babies to health unknown risks. Thus, the purpose of this commentary, was to analyze the perception about the use of medicinal plants by pregnant women and lactating registered in the "baby on board" NGO, Araraquara, São Paulo state, Brazil, between 2010 at 2013 . The group was constituted by 48 women, between the first and last trimester of pregnancy or whilst breastfeeding. Information was collected during group meetings by oral interview, using a questionnaire, as script. The nature of the study was a qualitative analysis. The results were based on reports about the use of medicinal plants by pregnant women during group meetings: use, indication of use, knowledge about risks. All participants received written and oral information about the study and they gave a written informed consent. The use of medicinal plants is a reality among pregnant and lactating women of the "baby on board" NGO. They reported that they feel that "natural" products are not harmful for their health. The primary information sources for the majority of women about medicinal plants during pregnancy are family, neighbors and herbalists. The plants most cited were: senna, chamomile, boldo, lemon balm, lemon grass. They were used mainly for: nausea, heartburn, indigestion, flatulence, intestinal and abdominal pain, anxiety, intestinal constipation and low milk production. The pregnant and lactating women lacked knowledge about the health risks of the use of medicinal plants and herbal medicines in pregnancy and lactation. They also reported difficulties in clarifying some questions about the use of medicinal plants with their doctors. The results of the present study showed that educative actions about the rational use of medicinal plants in pregnancy and breastfeeding could be part of the operating protocols to promote the maternal and child health programs in Araraquara. Thus, our results also suggest the importance of creating institutionalized places, to the implementation of continued education programs about rational use of medicinal plants in pregnancy and lactation. These targeted programs are not only for health professionals, but also for community members, pregnant women and breastfeeding. Our results pointed out the importance of guidance of doctors and healthcare professionals on the scientific studies about medicinal plants and herbal medicines and the risk/benefit of using herbs during pregnancy. Finally, it is noted the importance of the health professionals to inform women of childbearing on risks to their health, as well as on possibilities of utilization of herbs during fertile period, giving special attention to the potential risk of self-medication.
\end{abstract}

Keywords: Pregnancy; Breastfeeding; Educative group; Medicinal plants; Potential risks

\section{Introduction}

According to WHO [1], the medicinal plants are the therapeutic resource, more widely used in traditional medicine. This practice is based on the popular knowledge, oral transmission between generations and encourages community development, solidarity and social participation [2,3]. In Brazil, about $82 \%$ of the population uses the medicinal herbal products in their health care [2].

However, the medicinal plants that are used for the general population may have restricted its use in pregnancy and breastfeeding. One of the risks in the use of medicinal plants by the general population is the toxicity. In pregnancy can lead to risk the health of the woman and her fetus.

Several authors have described potential adverse effects arising from the use of medicinal plants in pregnancy, such as teratogenic, mutagenic, embriotoxic and abortifacient effects [4-8]. The mutagenic and teratogenic effects of the substances induce birth defects by injuring developing organs or disorganization and differentiation of the growth. Are environmental, chemical, physical and biological agents that can cause obstetric abnormalities and (or) fetal [9]. The risk of the teratogenicity is present throughout pregnancy, but is higher in embryogenesis stage, period in which occur to tissue differentiation and organogenesis [10].

Toledo et al. [11], from tests on rats, using aqueous extracts of the chapéu-de-couro (popular name in Brazil), proved that fetuses showed 
Citation: Moreira RRD, Camargo FR, Quílez AM, Salgueiro L, Cavaleiro C (2014) Medicinal Plants in Pregnancy and Lactation: Perception of the Health Risk and Practical Educational Group in Araraquara, São Paulo State, Brazil. J Gen Practice 2: 190. doi: $10.4172 / 2329-9126.1000190$

Page 2 of 6

mild hepatomegaly, bleeding points by the body and clammy skin. Almeida and Lemonica [12] proved the abortifacient effect of Coleus barbatus (falso-boldo, popular name in Brazil), in a study conducted in the pre-implantation period whose anti-implantation effect and delayed development.

But, if the women use the substances not recommended, in the prenatal period, is still possible that the development in the post-natal period, may suffer structural and metabolic changes [10].

In the Rio de Janeiro state, Brazil, a resolution was regulated about the use of medicinal plants by pregnant women, in seeks the need to ensure quality, safety and efficacy for the therapeutic use of medicinal plants [13]. The resolution has the purpose of to clarify to the general public and healthcare professionals in particular, about the dangers of indiscriminate use of medicinal species in pregnancy and lactation. This resolution is noteworthy because it takes into account the pregnant and lactating women, that are population group, that culturally, most use of medicinal plants. The resolution, also discusses the risks of indiscriminate use of medicinal species mainly during the first trimester of pregnancy and lactation. This resolution takes into account the toxic, teratogenic and abortifacient potential of various medicinal plant species and whose toxicological effects have not been investigated, as well as products that have proven toxic effects.

Therefore, the use of medicinal plants by pregnant women and lactating is a public health problem, since they make use of herbal unaware of these potential effects [8].

\section{Purpose of this Commentary}

Thus, the purpose of this commentary was to analyze the perception of use of medicinal plants by pregnant women and lactating registered in the "baby on board" NGO, Araraquara, São Paulo state, Brazil, between 2010 at 2013.

\section{Material and Methods}

\section{Target group}

The group was constituted of 48 women; enter the first and last trimester of pregnancy or breastfeeding, registered in NGO "baby on board", Araraquara, São Paulo state, Brazil, between 2010 at 2013.

\section{Data collection}

The authors conducted the focus group. Data were collected during group meetings of pregnant women, by oral interview, using a questionnaire, as script. The group used to meet at Saturdays, in the Non-governmental organization (NGO) "Baby aboard" of Araraquara, São Paulo state, Brazil, between 2010 at 2013.

The nature of the study was a qualitative analysis. The results were based on reports of women that are pregnant or lactating, addressing the form and therapeutic uses of medicinal plants, knowledge about risks of their use, perception of health risks for their fetus and babies, and the type of dialogue with their doctors.

All participants received written and oral information about the study and written informed consent was obtained.

\section{Results and Discussion}

Perception about the use of medicinal plants by women that are pregnant or lactating: plants associated with the reasons of the use, indication of use and information source.

The use of medicinal plants is a reality among pregnant and lactating women of the "baby on board" NGO.

They report that feel that "natural" products are not harmful health them.

The primary information sources for the majority of these women about medicinal plants during pregnancy are the family, neighbors and herbalists.

The medicinal plants most often cited were (in popular name in Brazil): alho, camomila, capim-limão, carqueja, cáscara-sagrada, cavalinha, boldo, confrei, erva-cideira, erva-doce, erva-de-santa-maria, espinheira-santa, funcho, guaco, hortelã, linhaça, losna, poejo, quebrapedra, romã, sálvia, sene and soja.

Is very important, emphasize here, that not all the plants sold with a popular name represent the same botanical species, and although known popularly by the same name, similar plants may not have the same properties or contain a different levels of toxicity.

The symptoms most often cited were: nausea, heartburn, indigestion, flatulence, intestinal and abdominal pain, anxiety, intestinal constipation and low milk production.

\section{Perception of Health Risks}

The pregnant women and lactating of the NGO, reported that following a drugs prescribed interruption by physician, their looked for "natural treatments", mainly medicinal plants. They reported the use of many plants that according to literature data are contraindicated in pregnancy and breastfeeding (Table 1). But, they report that the medicinal plants, are "natural" products, and are not harmful health them.

Therefore, the teratogenic and mutagenic effects, are reported for many medicinal plants, such as Mentha piperita L. (Lamiaceae) (hortelã-pimenta) [4,14], Ruta chalepensis/ Ruta graveolens (arruda) [15], Stryphnodendron polyphyllum, barbatimão [16], Lantana camara (cambará) [17], Echinodorus macrophyllus (Kunt) Mich. (chapéu-de-couro) [18], Vernonia condensate (falso-boldo) [12], Tripterygium wilfordii (vidreira) [18], Rhazya stricta [19], Senecio latifolius [20], Tabebuia sp. (ipê-roxo), showed teratogenic effects. The mutagenic effects showed for Bacharis trimera (Less.) DC. (Asteraceae) (carqueja) [21-24]. Many plants showed toxicity for the fetus or embryo. The embryotoxicity refers to the disruption of the embryonic or fetal development, the expense of doses that do not affect the maternal organism [10]. Some examples can be cited: Symphytum officinale L. (Boraginaceae) (confrei) is toxic to fetus. Mentha piperita L. (Lamiaceae) (hortelã-pimenta), Pfaffia glomerata Spreng (ginseng) originate malformation in newborn [11]. Salvia fruticosa Mill. (Lamiaceae) (sálvia) has genotoxic effects [25].

According Rodrigues et al. [26], in previous studies with Wistar rats, the periods of pre-deployment and post-deployment and organogenesis, are those in which one should avoid the use of medicinal plants that can cause adverse effects in pregnancy. The doses which could provoke these effects varied $0.500-7000 \mathrm{mg} \mathrm{kg}-1$ 
Citation: Moreira RRD, Camargo FR, Quílez AM, Salgueiro L, Cavaleiro C (2014) Medicinal Plants in Pregnancy and Lactation: Perception of the Health Risk and Practical Educational Group in Araraquara, São Paulo State, Brazil. J Gen Practice 2: 190. doi: $10.4172 / 2329-9126.1000190$

Page 3 of 6

day- 1 , and depends on the concentration that is the substance derived from the plant.

It is believed that exposure to the medicinal plants during pregnancy is responsible for only about $1 \%$ of fetal malformations. Although this percentage seems small, the total number is significant [10].

Many plants also can cause abortion. Abortion is the termination of pregnancy by the death of the embryo or fetus [27]. The abortifacient effects related to the use of medicinal plants in pregnancy, are also reported in the literature [4,21-23,28-32]. As example of the abortifacient plants are: Senna alexandrina Mill (Fabaceae) (sene) [4,30,33,35-37], Rhamnus purshiana DC (Rhamnaceae) and Rhamnus catharticus (Rhamnaceae) (cáscara-sagrada) [4,30,31,37], Mentha pulegium L. (Lamiaceae) (poejo) [4,38-40], Mentha arvensis L. (Lamiaceae) (hortelã-japonesa) [4,41], Chenopodium ambrosioides L. (Chenopodiaceae) (erva-de-santa-maria or mastruço) [4,42-46], Artemisia absinthium L. (Asteraceae) (losna) [4,30,31,37,47-49] among other.

The medicinal plants, also can cause adverse effects on breastfeeding, Allium sativum L. (Liliaceae) alho [31,50], Rhamnus purshiana DC (Rhamnaceae), Rhamnus catharticus (Rhamnaceae) cáscara- sagrada, Senna alexandrina Mill (Fabaceae) sene can cause cramps and diarrhoea in infant $[4,30,33,34-37]$. Others medicinal plants can cause reduction of milk, such as Glycine max (L.) Merr. (Fabaceae) soja, Maytenus aquifolium Mart. (Celastraceae) and Maytenus ilicifolia Mart. ex Reissek (Celastraceae) espinheira- santa $[31,51]$

It should be noted that many of these plants being used outside of the pregnancy, are effective for the general population, if used rationally.

It is also worth noting, that not all the plants sold with a popular name represent the same botanical species, and although known popularly by the same name, similar plants may not have the same properties or contain a significant level of toxicity.

So are many health risks for pregnant women, especially in the first trimester of pregnancy and lactation.

But, based in the reports of the pregnant and lactating women of the educational group of NGO, they showed not know the potential risks to their health, her fetus and her baby from the use of the medicinal plants and herbal medicines.

\begin{tabular}{|c|c|c|c|c|}
\hline Scientific name / Family & Popular name in Brazil & Contraindication & Adverse Effect & Reference \\
\hline Allium sativum L. (Liliaceae ) & alho & Breastfeed in Pregnancy & Cramps in infant & Mennella and Beauchamp, Brinker \\
\hline $\begin{array}{lll}\text { Artemisia } & \text { absinthium } & \text { L. } \\
\text { (Asteraceae) } & & \end{array}$ & losna & Breastfeeding & $\begin{array}{l}\text { Contractions, abortion, cramps } \\
\text { and convulsions }\end{array}$ & $\begin{array}{l}\text { Paris and Moyse, Duke, Teuscher } \\
\text { and Lindequist, Bisset, Alonso, } \\
\text { Brinker, Garcia }\end{array}$ \\
\hline $\begin{array}{l}\text { Bacharis trimera (Less.) DC. } \\
\text { (Asteraceae) }\end{array}$ & carqueja & Pregnancy & $\begin{array}{l}\text { Abortion, relaxing the uterus, } \\
\text { mutagenic }\end{array}$ & $\begin{array}{l}\text { Torres et al. , Alonso and } \\
\text { Desmarchelier et al., Peron et al. }\end{array}$ \\
\hline $\begin{array}{l}\text { Chenopodium ambrosioides L. } \\
\text { (Chenopodiaceae) }\end{array}$ & $\begin{array}{l}\text { erva-de-santa-maria, } \\
\text { mastruço }\end{array}$ & $\begin{array}{l}\text { Pregnancy, } \\
\text { Breastfeeding }\end{array}$ & $\begin{array}{l}\text { Contractions, abortion, vomiting } \\
\text { and torpor }\end{array}$ & $\begin{array}{l}\text { Hoehne, Roth et al., Estrella, } \\
\text { Montoya-Cabrera et al., Alonso, } \\
\text { Toll and Hurlbut }\end{array}$ \\
\hline $\begin{array}{l}\text { Cymbopogon citratus (DC) Stapf. } \\
\text { (Poaceae) }\end{array}$ & capim- santo / capim- limão & Pregnancy & Relaxing the uterus & Alonso \\
\hline $\begin{array}{lll}\begin{array}{l}\text { Equisetum } \\
\text { (Equisetaceae) }\end{array} & \text { arvense } & \text { L. }\end{array}$ & cavalinha & Pregnancy & Thiamine deficiency & Alonso, Blumenthal \\
\hline $\begin{array}{l}\text { Foeniculum } \\
\text { (Apiaceae) }\end{array}$ vulgare $\quad$ Mill. & funcho & Pregnancy & $\begin{array}{l}\text { Contractions, hormone action, } \\
\text { promotes menstruation, abortion }\end{array}$ & Malini et al., Shah et al. \\
\hline Glycine max (L.) Merr. (Fabaceae) & soja & $\begin{array}{l}\text { Pregnancy, } \\
\text { Breastfeeding }\end{array}$ & Reduction of milk & \\
\hline Linnum usitatissimum L. (Linaceae) & linhaça & Pregnancy & Promotes menstruation & Bisset, Brinker \\
\hline 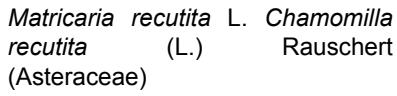 & camomila & Pregnancy & $\begin{array}{lr}\text { Abortion, } & \text { promotes } \\
\text { menstruation, relaxing the } \\
\text { uterus }\end{array}$ & Rodriguez et al., Alonso \\
\hline $\begin{array}{l}\text { Maytenus aquifolium Mart. } \\
\text { (Celastraceae) }\end{array}$ & espinheira- santa & Breastfeeding & Reduction of milk & Bringel et al., Brinker \\
\hline $\begin{array}{l}\text { Maytenus ilicifolia Mart. ex Reissek } \\
\text { (Celastraceae) }\end{array}$ & espinheira- santa & Breastfeeding & Reduction of milk & Bringel et al., Brinker \\
\hline Mentha arvensis L. (Lamiaceae) & hortelã-japonesa & Pregnancy & $\begin{array}{l}\text { Promotes } \\
\text { abortion }\end{array}$ & Alonso, Sharma and Jocob \\
\hline Mentha piperita L. (Lamiaceae) & hortelã-pimenta & Pregnancy & $\begin{array}{l}\text { Teratogenicity, promotes } \\
\text { menstruation, malformation in } \\
\text { newborn }\end{array}$ & Alonso, Lazutka et al. \\
\hline
\end{tabular}


Citation: Moreira RRD, Camargo FR, Quílez AM, Salgueiro L, Cavaleiro C (2014) Medicinal Plants in Pregnancy and Lactation: Perception of the Health Risk and Practical Educational Group in Araraquara, São Paulo State, Brazil. J Gen Practice 2: 190. doi: $10.4172 / 2329-9126.1000190$

Page 4 of 6

\begin{tabular}{|c|c|c|c|c|}
\hline Mentha pulegium L. (Lamiaceae) & poejo & Pregnancy & $\begin{array}{l}\text { Promotes menstruation, } \\
\text { abortion }\end{array}$ & $\begin{array}{l}\text { Sulivan et al., Tyler, Madyastha } \\
\text { and Raj, Alonso }\end{array}$ \\
\hline $\begin{array}{l}\text { Mikania glomerata Spreng } \\
\text { (Asteraceae) }\end{array}$ & guaco & Pregnancy & Haemorrhage & Alonso \\
\hline Peumus boldus M. (Monimiaceae) & boldo-do-chile & Pregnancy & Abortion & $\begin{array}{l}\text { Almeida et al., Almeida and } \\
\text { Lemonica }\end{array}$ \\
\hline $\begin{array}{lll}\text { Phyllantus } & \text { niruri } & \text { L. } \\
\text { (Euphorbiaceae) } & & \end{array}$ & quebra- pedra & Pregnancy Breastfeeding & Abortion, cramps and diarrhoea & Alonso \\
\hline Pimpinella anisium L. (Apiaceae) & anis ou erva-doce & Pregnancy & $\begin{array}{l}\text { Hormone action, promotes } \\
\text { menstruation }\end{array}$ & Bisset, Alonso, Blumenthal \\
\hline Punica granatum L. (Punicacae) & romã & Pregnancy & Contractions, abortion & Brinker \\
\hline $\begin{array}{l}\text { Rhamnus } \\
\text { (Rhamnaceae) }\end{array}$ & cáscara- sagrada & Pregnancy Breastfeeding & $\begin{array}{l}\text { Stimulating the uterus, abortion, } \\
\text { cramps and diarrhoea in infant }\end{array}$ & Bisset, Alonso, Brinker \\
\hline $\begin{array}{l}\text { Rhamnus purshiana DC } \\
\text { (Rhamnaceae) }\end{array}$ & cáscara- sagrada & Pregnancy Breastfeeding & $\begin{array}{l}\text { Contractions, abortion, cramps } \\
\text { and diarrhoea in infant }\end{array}$ & Alonso, Bisset, Brinker, Garcia \\
\hline Salvia fruticosa Mill. (Lamiaceae) & sálvia & Pregnancy & Abortion, genotoxic & Elbetieha et al. \\
\hline Salvia officinalis L. (Lamiaceae) & sálvia & Pregnancy Breastfeeding & $\begin{array}{l}\text { Contractions, hormone action, } \\
\text { abortion, reduction of milk }\end{array}$ & Bisset, Alonso \\
\hline Senna alexandrina Mill. (Fabaceae) & sene & Pregnancy Breastfeeding & $\begin{array}{l}\text { Contractions, } \\
\text { diarrhoea in infant }\end{array}$ & $\begin{array}{l}\text { Franz, Bisset, Garcia-Villar, } \\
\text { Alonso, Garcia, Blumenthal }\end{array}$ \\
\hline $\begin{array}{lll}\text { Symphytum } & \text { officinale } & \mathrm{L} . \\
\text { (Boraginaceae) } & & \end{array}$ & confrei & Pregnancy Breastfeeding & $\begin{array}{l}\text { Hormone action, toxic to fetus, } \\
\text { hepatotoxic }\end{array}$ & Tyler, Bisset, Alonso, Garcia \\
\hline
\end{tabular}

Table 1: Medicinal plants: scientific and popular name in Brazil. Contraindications and adverse effects in pregnancy and lactation.

To avoid exposing pregnant women to these adverse effects from the use of medicinal plants, some actions at the local level should be developed.

\section{Dialogue between doctors and pregnant and lactating women and lactating of NGO}

Several authors have discussed the effective doctor-patient communication [52-54]. The communication is a central clinical function in building a therapeutic doctor-patient relationship. This is important in the delivery of quality health care to pregnant women.

According, Fong Ha et al. [52], the breakdown in the doctor-patient relationship, causes dissatisfaction and many complaints by patients.

The women also report that they do not discuss the use of medicinal plants with doctors, because they feel that natural products are not harmful health them. It was also reported that doctors do not inquire about the use of medicinal plants or products derived from them.

In the present study, the doctor-patient relationship also is a problem, damaging in part, health promotion pregnant woman and lactating. The women, also report, difficulties in clarifying some questions about the use of natural products and medicinal plants with your doctor, because the time of the medical consultation, is very limited.

Undoubtedly, doctor-patient communication is a major component of the process of health care, but the health educative actions (besides the medical office), has been playing a role, no means least, responsible for the transmission and broadcasting of knowledge, change in healthrelated habits.
The dialogue with the pregnant and lactating women, guidance of physicians and others health professionals, associated with the scientific study of medicinal plants, are actions urgent and extremely important in maternal and child clinics.

Many health problems of the mother, her fetus and her baby, arising out of irrational and indiscriminate use of medicinal plants.

\section{Interface: Health and Education}

In the construction of health knowledge, all the actors of society has its pivotal role. The rational use of medicinal plants, demand educational approaches that enhance the creation of spaces that encourage appreciation of knowledge, prudence and the review, by health professionals, community leaders and users [55]. Health promotion through actions related to the rational use of medicinal plants, involves the rescue of cultural values, while stimulating intersectoral actions, encouraging the link between the health team and the community, between professionals and users, encouraging autonomic care awareness, promoting local development, intersectoral and community participation [56,57]. Therefore, lay knowledge, popular and traditional can be seen as an opportunity to approach the health professional with the user [56,57]. In this context, permanent and popular education in health services and spaces in community, about the rational use of medicinal plants should be used as care and health promotion strategy, with a decentralization of power-scientific knowledge [58]. Thus, the community and organized users with its traditions, values and knowledge, as well as academic institutions, research and teaching, with its scientific criteria, can contribute to building knowledge ecology of medicinal plants in dialogues and 
Citation: Moreira RRD, Camargo FR, Quílez AM, Salgueiro L, Cavaleiro C (2014) Medicinal Plants in Pregnancy and Lactation: Perception of the Health Risk and Practical Educational Group in Araraquara, São Paulo State, Brazil. J Gen Practice 2: 190. doi: $10.4172 / 2329-9126.1000190$

Page 5 of 6

decisions about the uses/guidelines/requirements for medicinal plants and herbal medicines in primary health care and autonomous use.

\section{A Call for Action}

Thus, Non-Governmental Organizations and Women Associations have played an important role in health promoting of the pregnant and lactating women. Actions as developing public health practice, promoting lectures, rounds of conversation and group discussion, may helping build awareness and promote self-care in maternal and child health. Promote interaction between community and health staff through meetings to share experiences, such as identification of medicinal plants, the form and method of preparation are used by the community and therapeutic indication. Those already skilled professionals, it is present scientific evidence, correlating the popular knowledge, study of chemical composition, pharmacological action, toxicity, drug interactions, contraindications, dosage, botanical aspects, agronomic and nutritional most common plants in the community, with highlighting the different species that can be recognized with the same common name.

The results of the present study showed that educative actions about the rational use of the medicinal plants in pregnancy and breastfeeding could be part of the operating protocols in promoting the maternal and child health programs in Araraquara. Thus, our results also indicate for the creation of institutionalized spaces (for example in Health Centers), to the implementation of continued education programs in rational use of the medicinal plants in pregnancy and lactation. And these programs targeted not only to health professionals, but also for community members, the pregnant women and breastfeeding.

The shortage of educational materials in health service publishes directed to the rational use of medicinal plants in pregnancy and lactation, also makes us think the development the educative materials (cd, handbooks, softwares), for use in infant maternal clinics, in order to inform and alert to this problem.

The result of the present study, also, makes us reaffirm, the importance of guidance of the doctors, and healthcare professionals, about the scientific studies about medicinal plants and herbal medicines as well as the risk/benefit of using herbs during pregnancy.

Finally, it is noted the importance of the health professionals, and community workers and leaders to inform women of childbearing and pregnant women on risks to their health, as well as on possibilities of utilization of medicinal plants in pregnancy age, calling, especially attention to the potential risk of self-medication.

The best suggestion then, continues to be prevention. So the guidance for pregnant women is to not use any herb or herbal medicine, without the prior knowledge of your doctor, as in previous studies some plants may have embryotoxic, abortifacient and teratogenic effects.

An educational booklet is being prepared about the rational use of medicinal plants in pregnancy and breastfeeding, and will soon be launched and offered partnership to government health bodies, as part of the education strategy in maternal and child health.

\section{Author Contributions}

RRDM was involved in study design, data collection, supervision is and the main author writing the paper and project implement action, provided advice on questionnaire development and in literature review.

FRC data collection and literature review.

AMQ data collection and involved in reviewing the paper for submission and in literature review.

LS involved in reviewing the paper for submission.

CC helping the English version and involved in reviewing the paper for submission.

All authors have read and approved the final manuscript.

\section{Acknowledgement}

The authors gratefully acknowledge the assistance of Ms. Michele Assalve, president of the NGO "Baby aboard" of Araraquara, São Paulo state, Brazil. Professor Dr. Márcia da Silva in memoriam do Departamento de Fármacos e Medicamentos de Faculdade de Ciências Farmacêuticas- UNESP- Araraquara- São Paulo- Brasil. FUNDUNESP and PROEX-UNESP for financial support. American Eagle Editing Office LLC for helping with preparation of the English version.

\section{References}

1. WHO- WORLD HEALTH ORGANIZATION. Ensayo clínico aleatorizado de control prenatal de la OMS: manual para la puesta en práctica del nuevo modelo de control prenatal. Ginebra, 2002.

2. Ministério da Saúde. Secretaria de Atenção à Saúde. Departamento de Atenção Básica. Política Nacional de Práticas Integrativas e Complementares no SUS, PNPIC, SUS (2006) Brasília: Ministério da Saúde, 92 p. (Série B. Textos Básicos de Saúde).

3. Rodrigues HG, Meireles CG, Lima JTS, Toledo GP, Cardoso JL, et al. (2011) Efeito embriotóxico, teratogênico e abortivo de plantas medicinais. Rev Bras Plantas Med 13: 359-366.

4. Alonso JR (1998) Tratado de Fitomedicina. Bases clínicas e farmacológicas. Isis editorial Buenos Aires, Argentina.

5. Mengue SS, Mentz LA, Schenkel EP (2001) Uso de Plantas Medicinais na Gravidez. Rev Bras Farmacogn 11: 21-35.

6. Ernst E (2002) Herbal medicinal products during pregnancy: are they safe? BJOG 109: 227-235.

7. Nordeng H, Havnen GC (2004) Use of herbal drugs in pregnancy: a survey among 400 Norwegian women. Pharmacoepidemiol Drug Saf 13: 371-380.

8. Veiga Júnior VF, Pinto AC, Maciel MAM (2005) Plantas medicinais: cura segura? Química Nova 28: 519-528.

9. Embiruçui EK, Sorte NB,Vidal R, Lessa L, Panão E, et al. (2005) Risco teratogênico: a percepção em diferentes segmentos da população. Rev Ciências Méd Biol 4: 201-207.

10. Araujo RC (1998) Estudo toxicológico das drogas. Correlação clínicopatologia. In: SILVA, P. Farmacologia. 5.ed. Rio de Janeiro: Guanabara Koogan 20: 131-150.

11. Toledo MS et al. (2004) Comparação da Fitotoxicidade dos extratos aquosos de Echinodorus macrophyllus (Kunt) Mich. em ratas prenhes. Rev Horti Bras 22: 493.b

12. Almeida FC, Lemonica IP (2000) The toxic effects of Coleus barbatus B. on the different periods of pregnancy in rats. J Ethnopharmacol 73 : 53-60.

13. Brasil (2002) Secretaria de Estado de Saúde. Resolução SES/RJ n. 1757 de $18 \mathrm{de} \mathrm{fev.} \mathrm{De} \mathrm{2002.} \mathrm{Contra} \mathrm{indica} \mathrm{o} \mathrm{uso} \mathrm{de} \mathrm{plantas} \mathrm{medicinais} \mathrm{no} \mathrm{âmbito}$ do Estado do Rio de Janeiro e dá outras providências. Diário Oficial, Rio de Janeiro, ano XXVII, n. 33, parte I, de 20 de fev.

14. Lazutka JR, Mierauskiene J, Slapsyte G, Dedonyte V (2001) Genotoxicity of dill (Anethum graveolens L.), peppermint (Menthaxpiperita L.) and 
Citation: Moreira RRD, Camargo FR, Quílez AM, Salgueiro L, Cavaleiro C (2014) Medicinal Plants in Pregnancy and Lactation: Perception of the Health Risk and Practical Educational Group in Araraquara, São Paulo State, Brazil. J Gen Practice 2: 190. doi: $10.4172 / 2329-9126.1000190$

Page 6 of 6

pine (Pinus sylvestris L.) essential oils in human lymphocytes and Drosophila melanogaster. Food Chem Toxicol 39: 485-492.

15. Gonzales JR, Benavides V, Rojas R, Pino J (2006) Efecto embriotóxico y teratogénico de Ruta chalepensis L. «ruda», en ratón (Mus musculus). Rev Peru Biol 13: 223-225.

16. Vitral GSF, Peters VM, Guerra MO (1987) Mecanismos da ação embriótoxica do barbatimão (Stryphnodendron polyphyllum M.). Repr and Clim 3: 222-226.

17. Mello FB, Jacobus D, Carvalho K, Mello JR (2005) Effects of Lantana camara (Verbenaceae) on general reproductive performance and teratology in rats. Toxicon 45: 459-466.

18. Chan WY, Ng TB (1995) Adverse effect of Tripterygium wilfordii extract on mouse embryonic development. Contraception 51: 65-71.

19. Rasheed RA, Bashir AK, Ali BH, Padmanabhan R (1997) Effect of Rhazya stricta on the developing rat fetus. Reprod Toxicol 11: 191-199.

20. Steenkamp V, Stewart MJ, van der Merwe S, Zuckerman M, Crowther NJ (2001) The effect of Senecio latifolius a plant used as a South African traditional medicine, on a human hepatoma cell line. J Ethnopharmacol 78: 51-58.

21. Peron AP, Felipes J, Mattge GI, Cantagalli LB, Mariucci RG, Vicentini VEP (2008) Avaliação mutagênica das plantas medicinais Baccharis trimera Less. e Solanum melongena L. em células de medula óssea de ratos Wistar. Rev Bras Biocien 6: 127-130.

22. Alonso J, Desmarchelier C (2006) Plantas medicinales autóctonas de la Argentina. Bases científicas para su aplicación en atención primaria de la salud. Buenos Aires: LOLA 663.

23. Torres LM, Gamberini MT, Roque NF, Lima-Landman MT, Souccar C, et al. (2000) Diterpene from Baccharis trimera with a relaxant effect on rat vascular smooth muscle. Phytochemistry 55: 617-619.

24. Toledo MRS, Silva CCA, Antonello D, Pimenta KR, Vieira MC, Ramos MBM, Heredia ZNA, Scalon SPQ, Bazzano TSC (2004) Extratos aquosos de Pfaffia glomerata $S$. e seu efeito tóxico em ratas prenhes. Rev Horti Bras 22: 493.a

25. Al-Hamood MH, Elbetieha A, Alkofahi A, Bataineh H (1998) Reproductive toxicity potentials of Salvia fruticosa (Labiatae) in rats. J Ethnopharmacol 61: 67-74.

26. Rodrigues FM, Mourelle, JF, Guitierrez, ZP (1996) Actividad espasmolitica del extracto fluido de Matricaria recutita (manzanilla) em organos aislados. Rev Cubana Plant Med 1: 19-24.

27. Hardy E, Costa RG, Rodrigues T, de Moraes TM (1994) [Current characteristics associated with a history of induced abortion]. Rev Saude Publica 28: 82-85.

28. Malini T, Vanithakumari G, Megala N, Anusya S, Devi K, et al. (1985) Effect of Foeniculum vulgare Mill. seed extract on the genital organs of male and female rats. Indian J Physiol Pharmacol 29: 21-26.

29. Shah AH, Qureshi S, Ageel AM (1991) Toxicity studies in mice of ethanol extracts of Foeniculum vulgare fruit and Ruta chalepensis aerial parts. J Ethnopharmacol 34: 167-172.

30. Bisset NG (1994) Herbal Drugs and Phytopharmaceuticals. CRC Press, London.

31. Brinker F (1998) Herb Contraindications and Drug Interactions (2th ed). Ecletic Medical Publications, Sandy, Oregon.

32. Almeida ER, Melo AM, Xavier H (2000) Toxicological evaluation of the hydro-alcohol extract of the dry leaves of Peumus boldus and boldine in rats. Phytother Res 14: 99-102.

33. Blumenthal M (1998) The complete German Commission E Monographs: therapeutic guide to herbal medicines. Austin, American Botanical Council.
34. 34. Blumenthal M (2000) Interactions between herbs and conventional drugs: introductory considerations. In: Herbs-everyday reference for health professionals. Otawwa, Canadian Pharmacists Association.

35. Franz G (1993) The senna drug and its chemistry. Pharmacology 47 Suppl 1: 2-6.

36. Garcia-Villar A (1988) Evaluation of the effects of Sennesides on Uterine motility of the pregnant ewe. Pharmacol 36: 203-211.

37. Garcia AA (1998) Fitoterapia: vademecum de prescripción. (3th ed) Barcelona, Masson.

38. Tyler V (1987) The new honest herbal. Philadelphia, Stickley.

39. Sullivan JB Jr, Rumack BH, Thomas H Jr, Peterson RG, Bryson P (1979) Pennyroyal oil poisoning and hepatotoxicity. JAMA 242: 2873-2874.

40. Madyastha KM, Raj CP (1994) Effects of menthofuran, a monoterpene furan on rat liver microsomal enzymes, in vivo. Toxicology 89: 119-125.

41. Sharma N, Jocob D (2001) Antifertility investigation and toxicological screening of the petroleum ether extract of the leaves of Mentha arvensis L. in male albino mice. J Ethnopharmacol 75: 5-12.

42. Estrella E. (1995) Plantas medicinales amazonicas: realidad y perspectivas. Lima: Protempore.

43. Roth L, Daunderer M, Kormann K. (1988) Giftpfianzen - Pfianzengifte: Vorkommen, Wirkung, Therapie, Allergische und phototoxische Reaktionen. Men: Ecomed 1119.

44. Hoehne FC. (1939) Plantas e substâncias vegetais e medicinais. São Paulo: Graphicars, 355.

45. Montoya-Cabrera MA, Escalante-Galindo P, Meckes-Fisher M, SánchezVaca G, Flores-Alvarez E, et al. (1996) [Fatal poisoning caused by oil of epazote, Chenopodium graveolens]. Gac Med Mex 132: 433-437.

46. Toll LL, Hurlbut KM. (Eds). (2000) POISINDEX System. MICROMEDEX, Inc., Englewood, Colorado, 105.

47. Paris RR, Moyse H (1971) Précis de matière médicale. v.3. Paris: Masson.

48. Teuscher E, Lindequist U. (1994) Biogene Gifte. Stuttgart: Fischer.

49. Duke J (1985) CRC Handbook of Medicinal Herbs. Boca Raton: CRC 677.

50. Mennella JA, Beauchamp GK (1991) Maternal diet alters the sensory qualities of human milk and the nursling's behavior. Pediatrics 88: 737-744.

51. Bringel AS, Fong H, Farnworth N (1976) Antifertility screening of selected plants in female rats. L Loydia 39: 475.

52. Ha JF, Longnecker N (2010) Doctor-patient communication: a review. Ochsner J 10: 38-43.

53. Hall JA, Roter DL, Rand CS (1981) Communication of affect between patient and physician. J Health Soc Behav 22: 18-30.

54. Stewart MA (1995) Effective physician-patient communication and health outcomes: a review. CMAJ 152: 1423-1433.

55. Carvalho SR (2004) [The multiple meanings of "empowerment" in the health promotion proposal]. Cad Saude Publica 20: 1088-1095.

56. Antonio GD, Tesser DC, Moretti-Pires RO (2013) Contribuições das plantas medicinais para o cuidado e a promoção da saúde na atenção primária à saúde. Interface (Botucatu) 17: 615-633.

57. Antonio GD1, Tesser CD2, Moretti-Pires RO2 (2014) Phytotherapy in primary health care. Rev Saude Publica 48: 541-553.

58. Santos RL, Guimarães GP, Nobre MSC, Portela AS (2011) Análise sobre a fitoterapia como prática integrativa no Sistema Único de Saúde. Rev Bras Plantas Med 13: 486-491. 